\title{
Need Analysis on Developing Teaching Instruments of Mathematics for Senior High School
}

\author{
${ }^{1}$ Septiana Wijayanti, ${ }^{1}$ Joko Sungkono \\ ${ }^{1}$ Widya Dharma University \\ e-mail: septiana.wijaya@unwidha.ac.id,
}

\begin{abstract}
This study aims to analyze the needs of developing teaching instruments of geometry, especially in solid figure, by using creative problem solving (CPS) with somatic, auditory, visual, and intelligence (SAVI) based. This is qualitative study. The subject in this study is the students of Class XII in SMA Negeri 1 Grobogan and mathematics teachers who teach that class in this school. Whereas the respondents are five students of Class XII MIPA 1 in SMA Negeri 1 Grobogan and four mathematics teachers who teach that class in this school. This study employs purposive sampling to gain the response about learning material of Curriculum 2013 which has been applied. The techniques of collecting the data in this study are observation, interview, and questionnaire. The data triangulation is used as the validity of the data in this study by comparing the data from the result of observation, interview, and questionnaire. The member checking is also used in order to ask the subject of the study about the result of the study. The conclusions of the study are as follow: 1) developing teaching instruments by using CPS with SAVI based is very appropriate since it can facilitate the teacher in teaching learning process and adapt the students' characteristic in learning, 2) developing teaching instruments by using CPS with SAVI based is also very appropriate to conduct to fulfill Curriculum 2013 needs, whereas the learning material in the school is not available yet.
\end{abstract}

Keywords: need analysis; developing learning material

\section{INTRODUCTION}

In line with the implementation of Curriculum 2013 which is replacing KTSP, Curriculum 2013 experiences the fast changes, so it gives the significant impact of teaching and learning process in the class. Those changes are done to gain the purposes of Curriculum 2013 that is, to prepare Indonesian people to have the personal life ability, become the faithful, productive, creative, innovative, and affective citizen, and also give contribution in the social, nation, and globalization [1]. To fulfill those purposes, learning practice in Curriculum 2013 still has some problems, such as making learning instruments, adaptation with the content in Curriculum 2013, teacher's readiness in learning process, implementation of creative and innovative learning method, and the availability of source books $[2 ; 3]$. Teacher must look at the changes of 
Curriculum 2013 as something which build and complete the education system in Indonesia. So, teacher is claimed to adapt Curriculum 2013 in giving teaching and learning on choosing learning media, learning method, and learning source [4].

The structure change toward the implementation Curriculum 2013 is applied to all subjects, one of them is Mathematics which has more portions, and moreover Mathematics is the main subject in school. In the previous curriculum, Mathematics is learned by emphasizing the concept mastery to gain cognitive attainment. So, the applied learning method is the conventional method, such as lecturing. Lecturing method is a traditional method which becomes a means of communication between teacher and students in teaching and learning activity, and it is reputed as the interesting method of teacher who is great in speaking [5;6]. However, lecturing method, in fact, has some disadvantages, such as this method become boring if it is applied in the subject with longer time in one meeting; the student becomes passive, it is hard to control the student's achievement in learning; and the learning is focused on teacher as the information giver of learning source and material [5,7].

Moreover, there has been done the problem finding by spreading the questionnaire and conducting the interview with the Senior High School students Class XII and Mathematics teacher in SMA Negeri 1 Grobogan. It shows that after following Mathematics subject with solid figure materials, students still consider that this material is abstract, so they have some difficulties in solving the problems; there is no source book, so the students are confuse in finding reference to study and it also make the teacher has difficulty in learning the material; the teacher is lack of creativity to give real example which is appropriate with daily life; and the teacher does also not use enough instrument to practice. Due to the lacking of learning process, there need to develop a learning instrument which can support the students to develop their creativity in solving the mathematics problem and making the teacher easier to teach mathematics. It is needed to develop learning instruments, such as lesson plan (RPP), student's worksheet (LKS), and learning source with Creative Problem Solving (CPS) with Somatic, Auditory, Visual, and Intelligence (SAVI) based learning model.

CPS is one learning strategy made to individual, team, and institution which the inner process has some variations by involving adult. In its development, CPS gives some impacts as follows. 1) CPS learning has the final purpose to emphasize the CPS implementation in facing the important and meaningful challenges and problems, 2) it becomes 'the bridge' between competence standard in learning process, 3) CPS is a flexible learning strategy and it can be used to reflect from the conventional learning, 4) it can connect the students, learning process, context in learning, and learning result [8]. Same idea from Puccio, Murdock, \& Mance [9] who state that CPS is a model of cognitive thinking skill since one function of this model is to develop one thinking process to solve the complex problem, the learning process functions to guide and direct one creativity thinking to act creatively, the learning content functions to help someone to employ the chance in hard condition and have ideas as the solution of the problem. According to Isrok'atun [10] in CPS learning, the students will find ideas through thinking process to find the helping idea to find the solution and they can get the evidence to the correct answer.

Although in its development, CPS has been revised to become perfect. But, the implementation of CPS in Mathematics learning still has some disadvantages as follows: not all materials can apply CPS easily, either in abstract material, material which uses learning instrument, or learning media; the time allocation to CPS learning 
is longer than other, in one meeting, we cannot fulfill the intended competency; and students' creativity skill are different one another, it makes they are confuse in deciding the correct answer.

Since there is the different student's creativity skill in solving the problem, the researcher wants to combine the CPS learning with SAVI learning and also develop CPS learning with SAVI based. This study is conducted by the researcher since SAVI learning is one which adds the physical movement with the intellectual activity and uses the five senses. The learning can be taken place optimally because it is conducted with somatic, auditory, visual, and intellectually ways [11]. According to Andianti [12], the learning which implemented SAVI can give significance influence toward the increasing of student's mathematics communication skill. Ginting \& Hermansyah [13] also state that the learning which implemented SAVI can increase the learning quality, especially in increasing the students to be more active.

Geometry is one important material in Mathematics. In Curriculum 2013 Revision 2016, Geometry in solid figure is the compulsory material which must be learned by students of Class XII either in senior high school (SMA/MA) or vocational high school (SMK/MAK). The learning in solid figure material needs the learning instrument which can support the learning in the class. The available learning instruments still have many weaknesses as follows. 1) Lesson plan (RPP) is develop in teacher's subject group (MGMP), so it does not represent yet the teacher and students' characteristic in each school, 2) The teacher does not arrange the worksheet yet, so the students have difficulties in solving the problems of solid figure material, 3) the new source book of Curriculum 2013 Revision 2016 is not available yet. Concerning about the based competency in solid figure materials of Curriculum 2013 which is regulated in Permendikbud No.24 Year 2016 that are, 3.1 describe the distance in the space (between point, point to line, and point to field) and 4.1. determine the distance in the space (between point, point to line, and point to field).

Based on the background of the study above, this study tries to find whether the special learning instrument which implements CPS learning model with SAVI based to solid figure material is needed to observe or not. Based on the explanation above, in making success to the achievement competency in Curriculum 2013 which also determines the success of Curriculum 2013 in school, it needs to develop learning instrument for lesson plan (RPP), student's worksheet (LKS), and learning sources, especially solid figure material. By considering the operational need and school's support capacity, this study aims to produce CPS with SAVI based learning instrument.

\section{METHOD OF THE STUDY}

This is a qualitative study. Qualitative is collecting, analyzing, and interpreting the comprehensive narration and visual data to gain the knowledge of certain phenomena [14]. The analysis is about the need of developing CPS with SAVI based learning instrument for lesson plan (RPP), student's worksheet (LKS), and learning sources which can become the reference to develop learning instrument. The subject in this study is the students of Class XII in SMA Negeri 1 Grobogan and mathematics teachers which teach that class in this school. This study employs purposive sampling technique, where the researcher chooses individual or group intentionally to gain the complete information [15]. Whereas the respondents are five students of Class XII MIPA 1 in 
SMA Negeri 1 Grobogan and four mathematics teachers who teach that class in this school. The respondents is hoped that it can become the consideration in validity and the effectiveness of learning instrument which is made.

The data collection techniques are observation, interview, and questionnaire. Observation is conducted in the class which material is solid figure during the teaching and learning process. The researcher takes a note from the observation result in the student and teacher's observation sheets which have been prepared. Student's observation sheet is filled with student's responses during the teaching and learning process; student's activity in the teaching and learning process; and student's problem during the teaching and learning process. Teacher's observation sheet is about lesson plan implementation that been prepared by mathematics teacher, learning method that been done during learning process of solid figure material, and learning source which used in learning process of solid figure material. Observation sheet describes about the obstacles which are happened during the teaching and learning process. Interview is conducted by the researcher; she prepares the interview guideline, so the interview is on the given topic. It is done to know the school support toward the development of CPS with SAVI based learning instrument. Then, questionnaire, which has been validated by the expert judgment, gives to the mathematics teacher and students of Class XII. The questionnaire consists of twenty questions to the student's need and twenty five questions to the teacher's need. Those are arranged by the researcher with the indicator which connected to the learning method, source book, and student's response toward the development of learning instrument in solid figure material. The questionnaire of the student's need toward the development of learning instrument in solid figure material includes: 1) the understanding and student's need toward solid figure, 2) the understanding and student's need toward solid figure learning source, 3) the student's need toward the content of solid figure learning source, 4) the student's expectation, whereas the questionnaire of the teacher's need toward the development of learning instrument includes: 1) the understanding and teacher's need toward the availability of learning instrument in solid figure material, 2) the teacher's need toward the content of solid figure learning instrument, 3) teacher's expectation.

This study focuses on the student and teacher's response about the development of CPS with SAVI based learning instrument in solid figure material. The data validity in this study is data triangulation, by comparing the data from observation result, interview, and questionnaire. The member checking is also done to re-ask the result study to the subject of the research.

\section{DISCUSSION}

This study is started by conducting the observation in SMA Negeri 1 Grobogan. The observation to the teacher and student, which is done, is about the development of learning instrument which implements the CPS with SAVI based learning model. The result of the observation toward students shows: 1) students are not active during mathematics learning in the class, 2) students are not creative in solving mathematics problems, 3) students are more interested in learning with learning media or instrument, 4) students have an obstacle since source book with Curriculum 2013 is not available yet, whereas the result of the observation toward teacher shows: 1) teacher is not understand how to develop learning instrument individually, 2) teacher cannot develop 
learning instrument individually, 3) teacher does not know the reference yet about development learning instrument, 4) teacher needs to join a training about development learning instrument, 5) learning activity are lecturing, discussion, and question-answer session, 6) teacher has an obstacle since the new source book with Curriculum 2013 is not available yet, 7) the available learning instrument cannot make the teacher easier in learning process.

After the observation was conducted, the researcher gives the questionnaire of teacher and student's need toward the development of learning instrument which implements CPS with SAVI based learning model. The questionnaire of student's need toward the development of learning instrument, especially solid figure material, can be seen that the thirty students' response of Class XII shows: 1) 85\% students give positive response to the understanding and student's need toward solid figure, students consider that solid figure is the important material, so it needs more time to learn. 2) $74 \%$ students give response that they need source book in solid figure material, they just use student's book which is published from Kemendikbud until now, and the worksheet cannot help the students to formulate on the concept of solid figure. 3) $90 \%$ students want that there is text material in source book, such as the example of questions which includes the series and understandable ways. 4) Student's expectations to solid figure material are as follows, the learning source of solid figure is made including exercises and the way to answer the question, so the student is easier to study solid figure, learning source is also made in interesting way by giving pictures, and so solid figure material is not abstract. Thus, students agree if the learning source of solid figure implements CPS with SAVI based learning model.

The questionnaire of teacher's need toward the development of learning instrument can be seen through the response of Mathematics teachers of Class XII, it shows that: 1) The teachers have already understand about the learning instrument, but they cannot arrange the learning instrument individually. They agree if there will be arrange that learning instruments of solid figure implements CPS with SAVI based learning model, moreover they think that to teach solid figure is difficult. They do not yet arrange lesson plan individually, they use learning source, such as teacher's book which is published from Kemendikbud [16], the student's worksheet (LKS), which is used, is student's exercise book on sale in the bookstore. 2) The lesson plan content of learning instrument has follow the newest regulation, however the teacher does not yet use the learning method, learning media, and variation sources. The worksheet, which is used, does not include the way which guides student to solve the problem. Learning source consists of the general explanation of the material. 3) Teacher's expectation is as follows, it is made the learning instruments such as lesson plan (RPP), student's worksheet (LKS) and learning source which can make the teacher easier to deliver solid figure material.

Interview with the teacher and student toward the development of learning instrument which implements CPS with SAVI based learning model was done. The result of the interview with four Mathematic teachers of Class XII in SMA Negeri 1 Grobogan shows that: 1) the changes of Curriculum 2015 is very fast, it makes the teacher has some obstacles in adapting the learning instrument, 2) there is no adaptation in the teacher's book that makes the teacher experiences the restrictiveness of reference, 3 ) teacher are not have skill in doing innovative leaning model with scientific learning based, 4) teacher does not yet decide the student's success indicator in solving the problem, 5) teacher is burdened with the administration agenda, 6) teacher is lack of 
training, so they cannot develop learning media. The interview with five students of C of Class XII in SMA Negeri 1 Grobogan shows that: 1) the changes of Curriculum 2013 is very fast, it makes the students confuse in adapting the learning process, 2) the student's book is not yet available, it makes they experiences the restrictiveness of reference, 3 ) the students do not know to solve the problem individually, 4) the students still considers that Mathematics is the hard and abstract subject, 5) the book and worksheet appearance is not interesting, it makes the students become lazy to explore in solve the problem, 6) the students agree if the learning source of solid figure implements CPS with SAVI based learning model.

After conducting observation, questionnaire, and interview, and then doing member checking to the teacher, it can be concluded some points as follows: 1) the teacher experiences the obstacles in developing learning instrument individually, 2) the learning instrument, which is arranged together in group by the Mathematics teachers, do not yet make easier in learning process, 3) the teacher is interested in CPS with SAVI based learning model, 4) teacher needs learning instrument of solid figure material which implements CPS with SAVI based learning model, so it can help student to create the creativity in solving the problem. Then, member checking was also done to the student, it can be concluded some points as follows: 1) the students still have difficulties in learning solid figure, 2) source book and worksheet do not yet help the students to solve the problem, 3) the students are interested in learning instrument of solid figure material which implements CPS with SAVI based learning model, 4) the students need training to emerge the creativity in solving the mathematics' problem.

\section{CONCLUSION}

Based on the result of the need analysis which has been done, it can be concluded that: 1) developing teaching instruments by using CPS with SAVI based is very appropriate since it can facilitate the teacher in teaching learning process and adapt the students' characteristic in learning, 2) developing teaching instruments by using CPS with SAVI based is also very appropriate to conduct to fulfill Curriculum 2013 needs, whereas the learning material in the school is not available yet.

By developing CPS learning model with SAVI based in solid figure materials, teachers can easier to teach since they do not need to develop new learning model in appropriate with solid figure materials. The learning instruments such as lesson plan (RPP), student's worksheet (LKS), and learning sources correspond to the character of the teacher and students.

This study refers to the Curriculum 2013 which applies educational technology for problem solving related to daily life. This can serve as a basis for developing learning products that can improve student performance and solve learning problems. From the results of needs analysis, the product of the development should meet the criteria of the effectiveness. Therefore, the development of learning products should be in accordance with the characteristics of students and teachers. 


\section{REFERENCES}

[1] Menteri Pendidikan dan Kebudayaan. (2013). Peraturan Mentri Pendidikan dan Kebudayaan No. 68 Tahun 2013 Tentang Kerangka Dasar dan Struktur Kurikulum Sekolah Menengah Pertama/ Madrasah Tsanawiyah.

[2] Susena, Triwahyuningsih, Supriyadi, \& Arif, D. B. (2016). Kesulitan-kesulitan Guru dalam Mengembangkan Rencana Pelaksanaan Pembelajaran Mata Pelajaran PKn Kurikulum 2013 di SMP se-Kota Yogyakarta. Prosiding Seminar Nasional Pendidikan Berkemajuan Dan Menggembirakan: Jatidiri LPTK PTM Untuk Pendidikan Yang Berkemajuan Dan Menggembirakan, 220-223.

[3] Ahmad, S. (2014). Problematika Kurikulum 2013 dan Kepemimpinan Instruksional Kepala Sekolah. Jurnal Pencerahan, 8(2), 98-108.

[4] Mustofa. (2014). Implikasi Kurikulum 2013 Terhadap Proses Belajar Mengajar. Mimbar Sekolah Dasar, 1(2), 185-190.

[5] Asmani, J M. 2011. 7 Tips Aplikasi Paikem. Yogyakarta: Divva Press.

[6] Gafur, A. (2012). Desain Pembelajaran: Konsep, Model, dan Aplikasinya dalam Perencanaan Pelaksanaan Pembelajaran. Yogyakarta: Ombak Dua

[7] Hermawati, L. (2012). Upaya Meningkatkan Keaktifan Belajar dan Hasil Belajar Akuntansi dengan Strategi Pembelajaran ARIAS Terintegrasi dengan Pembelajaran Active Learning Tournament Pada Siswa Kelas X AK 2 SMK Negeri 3 Surakarta. JuPe UNS, 2(3), 273-283.

[8] Treffinger, D. J., \& Isaksen, S. G. (2005). Creative Problem Solving: The History, Development, and Implications for Gifted Education and Talent Development. Gifted Child Quarterly, 49(4), 342357. https://doi.org/10.1177/001698620504900407

[9] Puccio, G. J., Murdock, M. C., \& Mance, M. (2005). Current Developments in Creative Problem Solving for Organizations. Korean Journal of Thinking \& Problem Solving, 15(2), 43-76.

[10] Isrok'atun. (2012). "Creative Problem Solving (CPS) Matematis". Presented at Seminar Matematika dan Pendidikan Matematika, November 10th, 2012

[11] Meier, D. (2005). The Accelerate Learning Handbook.

[12] Andianti, R.L; Irawati, R; Sudin, A. (2016). Pengaruh Pendekatan Somatic, Auditory, Visual, and Intellectual (SAVI) dalam Meningkatkan Kemampuan Komunikasi Matematis dan Motivasi Belajar Siswa Sekolah Dasar Pada Materi Pengolahan Data. Jurnal Pena Ilmiah, 1(1), 471-480

[13] Ginting, S. M., \& Hermansyah, A. (2012). Penerapan Model Pembelajaran Somatis Auditori dan Intelektual (SAVI) Berbantuan Media komputer Untuk Meningkatkan Kualitas Pembelajaran

[14] Gay, L. R., Mills, G. E., \& Airasian, P. W. (2012). Educational Research: Comperencies for Analysis and Applications. New Jersey: Pearson Education, Inc.

[15] Creswell, J. W. (2012). Educational Research: Planning, Conducting and Evaluating Quantitative and Qualitative Research. Boston: Pearson Education, Inc.

[16] Menteri Pendidikan dan Kebudayaan. (2016). Peraturan Menteri Pendidikan dan Kebudayaan No. 24 Tahun 2016 Tentang Kompetensi Inti dan Kompetensi Dasar Pelajaran Pada Kurikulum 2013 Pada Pendidikan Dasar dan Pendidikan Menengah. 